\title{
Opioids Modulate Stress-induced Proenkephalin Gene Expression in the Hypothalamus of Transgenic Mice: A Model of Endogenous Opioid Gene Regulation by Exogenous Opioids
}

\author{
David Borsook ${ }^{1,2,3}$ Olga Falkowski, ${ }^{1}$ Haim Rosen, ${ }^{5}$ Michael Comb, ${ }^{3}$ and Steven E. Hyman ${ }^{1,4}$ \\ ${ }^{1}$ Laboratory of Molecular and Developmental Neuroscience, Massachusetts General Hospital, Boston, Massachusetts \\ 02114, Departments of ${ }^{2} \mathrm{Anesthesia}$, ${ }^{3} \mathrm{Neurology}$, and ${ }^{4} \mathrm{Psychiatry}$, Massachusetts General Hospital, Harvard Medical \\ School, Boston, Massachusetts 02114, and ${ }^{5}$ Department of Molecular Virology, Hebrew University Jerusalem, Hadassah \\ Medical School, Jerusalem 91010, Israel
}

\begin{abstract}
Stressful stimuli strongly induce proenkephalin gene expression within the paraventricular nucleus (PVN) of the hypothalamus. A human proenkephalin- $\beta$-galactosidase fusion gene has previously been shown to give correct phenotypic expression and appropriate stress regulation within the hypothalamus of transgenic mice; this model provides high sensitivity, cellular resolution, and ready quantification of levels of proenkephalin gene expression. Here we describe use of this transgenic model to study modulation of stress-regulated gene expression in the PVN by opiates. Acute or subacute morphine administration prior to a hypertonic saline stress produced marked superinduction of transgene expression compared with hypertonic saline stress alone. In contrast, chronic morphine administration decreased basal expression of the transgene, and inhibited stress-induced expression of the transgene. The endogenous proenkephalin mRNA was induced in parallel with the transgene as demonstrated by in situ hybridization; the immediate-early gene $c$-fos was also regulated in parallel with the transgene. These data suggest that acute or subacute morphine administration sensitizes proenkephalin neurons within the PVN and other reglons of the hypothalamus to stress and that chronic morphine administration desensitizes this response. Because the molecular mechanisms regulating the expression of the transgene are well understood, this model provides a useful tool for investigating cellular and molecular effects of opioids on the hypothalamus.
\end{abstract}

IKey words: proenkephalin, enkephalin, opioid, stress, gene expression, transgenic mice, hypothalamus, paraventricular nucleus, c-fos]

Kosterlitz, Hughes, and colleagues (Hughes et al., 1975; Waterfield et al., 1976) hypothesized that chronic morphine treatment may result in agonist-induced feedback inhibition of en-

\footnotetext{
Received Feb. 15, 1994; revised May 20, 1994; accepted May 26, 1994.

We thank Richard J. Kitz, M.D. (Department of Anesthesiology); Barry Kosofsky, M.D., Ph.D., Andrew Strassman, Ph.D., and Rami Burstein, Ph.D., for advice and helpful discussions; William Posten for assistance with acquisition of computerized images; and Clifford B. Saper, M.D., Ph.D., for his useful comments.

This work was supported by U.S. Public Health Service Grants MH44160 and DA 07134 to S.E.H., and DA07745 to M.C.

Correspondence should be addressed to David Borsook, M.D., Ph.D., Laboratory of Molecular and Developmental Neuroscience, Massachusetts General Hospital East, CNY 2 Building 149, 13th Street, Charlestown, MA 02129.

Copyright (C) 1994 Society for Neuroscience $0270-6474 / 94 / 147261-11 \$ 05.00 / 0$
}

dogenous opioid biosynthesis, and that this suppression of endogenous opioid peptides, such as the enkephalins, may contribute to aspects of opioid dependence and withdrawal. Early studies designed to test this hypothesis found little change in steady-state brain enkephalin peptide levels. However, these studies did not address turnover rate or changes within restricted populations of cells. More recently, opioid agonists have been shown to decrease (Uhl et al., 1988) and opioid antagonists to increase (Tempel et al., 1992) expression of proenkephalin mRNA or enkephalin peptides in some cell types, suggesting a direct or indirect opioid receptor-mediated effect on endogenous opioid gene expression. At the molecular level, proenkephalin gene expression has been shown to be highly regulated by cAMP (Comb et al., 1986, 1988; Hyman et al., 1989) and neural activity (White et al., 1986; Lightman et al., 1987; Iadarola et al., 1988; Sonnenberg et al., 1989), both acting via an enhancer located between nucleotides -70 and -107 with respect to the transcription start site (Comb et al., 1988; Hyman et al., 1988, 1989; Nguyen et al., 1990).

The proenkephalin gene is expressed in functionally diverse regions of the nervous system (Fallon et al., 1986; Merchenthaler et al., 1986; Harlan et al., 1987). Within the hypothalamus, the proenkephalin gene is expressed in a complex pattern that includes the paraventricular nucleus (PVN), in which it is markedly induced by various stressful stimuli including hypertonic saline stress and naloxone-precipitated morphine withdrawal (Lightman et al., 1987; Harbuz et al., 1991; Watts, 1992; Borsook, 1994a,b). Increases in proenkephalin gene products within the PVN may represent part of a cascade of adaptations to stress leading to altered release of hypothalamic hormones including corticotrophin-rclcasing hormonc (CRH) (Lightman ct al., 1987).

We have produced a transgenic mouse model to study proenkephalin gene regulation utilizing a fusion gene that contains 3 $\mathrm{kb}$ of the 5 ' flanking sequences (including the second messengerinducible enhancer), exon 1 , intron $A$, part of exon 2 , and 1.2 $\mathrm{kb}$ of 3 ' flanking sequences of the human proenkephalin gene and the reporter gene Escherichia coli $\beta$-galactosidase (Borsook et al., 1992; Borsuok, 1994a,b). We have previously shown that this construct contains sufficient information to replicate the expression of the endogenous proenkephalin gene within the PVN and the supraoptic nucleus (SON) following various stressors. The present study was undertaken to determine the effect of opioid administration in modulating the response of PVN and SON neurons to stress using transgene expression and ex- 
pression of the immediate-early gene c-fos as markers of altered signal transduction.

\section{Materials and Methods}

\section{Animals}

In all experiments, adult male ENK 1.1 transgenic mice (20-30 gm) were used (Borsook et al., 1992). The animals were maintained in groups of five per cage with free access to food and water in an environmentally controlled animal facility on a 12:12 hr light/dark cycle. Experiments were performed at the same time on each day to avoid any circadian effects. At the end of each experiment, animals received an overdose of Avertin and were perfused with $4 \%$ paraformaldehyde; for in situ hybridization, the brains were rapidly removed following cervical dislocation. Except where specified, four animals per treatment group were used. All experiments were subject to the approval of the Research Committee for Animal Experimentation, which follows the guidelines of the Massachusetts General Hospital and of NIH for experimentation in animals.

\section{Animal surgery}

Some mice underwent minor surgery for the placement of subcutaneous pellets (see below). The mice were first lightly anesthetized with ether (Sigma, St. Louis), and then a small incision $(0.5 \mathrm{~cm})$ was made over the back and a small pouch made with sterile forceps. A pellet (morphine sulfate, naltrexone, or placebo pellet) was then implanted and the skin incision sutured with $2 / 0$ silk (Ethicon). The procedure lasted less that $2 \mathrm{~min}$ and the mice recovered rapidly from the anesthetic.

\section{Saline stress}

The methods used for saline stress have been described previously (Borsook et al., 1994a,b). Briefly, animals received $0.018 \mathrm{ml} / \mathrm{gm}$ of either hypertonic saline $(1.5 \mathrm{M})$ or normal saline $(0.15 \mathrm{M})$ via intraperitoneal injections. Robust induction of the transgene is observed $6 \mathrm{hr}$ after intraperitoneal injection; we therefore use the $6 \mathrm{hr}$ time point for all our assays of transgene expression following hypertonic saline injections, unless otherwise specified.

\section{Drug treatments}

Pellets were provided by the kind courtesy of Dr. Robert Walsh at the National Institutes of Drug Abuse. Morphine pellets $(8$ or $25 \mathrm{mg}$ ), naltrexone pellets ( 10 or $30 \mathrm{mg}$ ), or placebo pellets (containing Avicel PH$102,141.44 \mathrm{mg}$; magnesium stearate, NF, $1.5 \mathrm{mg}$; colloidal silicon dioxide, NF, $0.75 \mathrm{mg}$; and sterile water) were used in these experiments. All animals receiving morphine pellets demonstrated typical behavioral effects of morphine on waking up from the anesthetic after placement of the subcutaneous pellet. For acute morphine injections, morphine sulfate was dissolved in normal saline and injected $(10 \mathrm{mg} / \mathrm{kg}$, i.p.). Naloxone was dissolved in normal saline and injected $(50 \mathrm{mg} / \mathrm{kg}, \mathrm{s.c}$.$) .$

Naloxone-precipitated opioid withdrawal. Morphine pellets were inserted subcutaneously as described above. Animals were made morphine dependent by inserting $8 \mathrm{mg}$ pellets for $3 \mathrm{~d}$, and then the pellets were removed and replaced under ether anesthesia with $25 \mathrm{mg}$ pellets for $4 \mathrm{~d}$. On day 7 , withdrawal was induced by injection of naloxone $(50$ $\mathrm{mg} / \mathrm{kg}$, s.c.) and the mice were then killed $6 \mathrm{hr}$ later. Control animals received the same treatment except that placebo pellets were used in place of morphine.

Chronic morphine and naltrexone. Animals received the identical morphine regimen as above, but did not undergo precipitated withdrawal. Chronic naltrexone animals received naltrexone pellets $(10 \mathrm{mg}$ pellets for $7 \mathrm{~d}$, except where specified). Control animals received placebo pellets.

Acute and subacute morphine + saline. For acute treatment mice were injected with morphine sulfate $(10 \mathrm{mg} / \mathrm{kg}$, i.p.) $4 \mathrm{hr}$ prior to saline injection ( $0.15 \mathrm{M}$ or $1.5 \mathrm{~m}$ saline). Subacute morphine treatment consisted of an $8 \mathrm{mg}$ morphine pellet for $24 \mathrm{hr}$, followed by saline injection. Animals were killed $6 \mathrm{hr}$ after the saline injection.

Subacute naltrexone + saline. Mice received a $10 \mathrm{mg}$ naltrexone pellet and were injected with $1.5 \mathrm{~m}$ saline $24 \mathrm{hr}$ later. Animals were killed 6 hr after the saline injection.

Nondrug treatment controls. Some mice received only injections of $0.15 \mathrm{M}$ or $1.5 \mathrm{M}$ saline and were then killed $6 \mathrm{hr}$ later to rule out any unexpected effect of placebo implantation on expression of the transgene.

\section{In situ hybridization for endogenous proenkephalin $m R N A$}

To determine whether the endogenous proenkephalin gene was induced in a manner similar to the transgene, we repeated drug experiments and prepared tissue for in situ hybridization with a cDNA probe derived from the rat proenkephalin gene (Polakiewicz and Rosen, 1990; Rosen et al., 1990). The rat proenkephalin probe, a 417 bp PST 1 fragment subcloned from the rat proenkephalin gene, corresponded to bases $1243-$ 1559. Thus, the probe does not contain any of the human proenkephalin sequences contained within transgenc. For in sit $u$ hybridization, brains were rapidly removed from the animal after cervical dislocation, blocked, and snap frozen in isopentane at $-40^{\circ} \mathrm{C}$. Fourteen-micrometer sections of brain tissue were cut on a cryostat and thaw-mounted onto gelatincoated slides. In situ hybridization was performed exactly as we have previously described for this probe (Borsook et al., 1994a).

\section{$X$-gal staining}

$\mathrm{X}$-gal staining using the chromogenic substrate 5-bromo-4-chloro-3indolyl- $\beta$-D-galactopyranoside (Boehringer Mannheim, $\mathrm{NJ}$ ) was used to detect expression of $\beta$-galactosidase. The method for $\mathrm{X}$-gal staining was adapted from Price et al. (1987), and was used exactly as we have previously described (Borsook et al., 1994a). Briefly, mice were anesthetized with intraperitoneal injections of $0.4 \mathrm{ml}$ of $2.5 \%$ Avertin and then perfused with $4 \%$ paraformaldehyde in phosphate-buffered saline (PBS). The brains were removed, postfixed in 4\% paraformaldehyde for $1 \mathrm{hr}$, and placed in $30 \%$ sucrose solution overnight at $4^{\circ} \mathrm{C}$. Frozen serial sections $(50 \mu \mathrm{m})$ were placed on gelatin-coated slides. X-gal (Boehringer Mannheim, $\mathrm{NJ})$ dissolved in dimethyl formamide $(40 \mathrm{mg} / \mathrm{ml})$ was added to a mixer solution to give a final concentration of $1 \mathrm{mg} / \mathrm{ml}$. The mixer solution was made up as follows: $0.125 \mathrm{ml}$ of a $240 \mathrm{~mm} \mathrm{KFe} e^{2+} \mathrm{CN}$ solution, $0.125 \mathrm{ml}$ of a $240 \mathrm{~mm}$ solution of $\mathrm{KFe}^{3+} \mathrm{CN}, 2.5 \mathrm{ml}$ of a 0.2 M Na $\mathrm{PO}_{4}$ buffer, $1.0 \mathrm{ml}$ of $5 \mathrm{~m} \mathrm{NaCl}, 12 \mathrm{ml}$ of $4.9 \mathrm{M} \mathrm{MgCl}_{2}$ (Sigma), $3 \mathrm{ml}$ of NP-40, $6 \mathrm{ml}$ of $1 \mathrm{~N} \mathrm{NaOH}, 3 \mathrm{mg}$ of deoxycholic acid (Sigma, St. Louis), and $24.75 \mathrm{ml}$ of $\mathrm{dH}_{2} \mathrm{O}$ to which was added $1.43 \mathrm{ml}$ of a $2 \%$ $\mathrm{X}$-gal solution made up in dimethylformamide (Sigma, St. Louis). Slides were air dried overnight, dipped in xylene, and coverslipped with mounting medium (Cytoseal, Stephens Scientific, NJ). Brains from nontransgenic C57BL/6J mice (Jackson Laboratories, Bar Harbour, ME) were placed using the same protocol to rule out endogenous $\beta$-galactosidase-like activity.

\section{Fos immunocytochemistry}

Adult transgenic ENK 1.1 mice, 20-30 gm, were injected with morphine sulfate (Sigma; $10 \mathrm{mg} / \mathrm{kg}$, i.p.) in a volume of $0.2 \mathrm{ml}(n=6)$ or with $0.2 \mathrm{ml}$ of normal saline $(n=4)$. One hour after the injections, the mice were given an overdose of Avertin and perfused transcardially with 150 $\mathrm{ml}$ of $4 \%$ paraformaldehyde $(\mathrm{pH} \mathrm{7.4)}$ in $1 \times \mathrm{PBS}, \mathrm{pH} 7.4$. Immunohistochemistry for Fos protein was performed exactly as previously described (Borsook et al., 1994b) using a specific affinity-purified polyclonal rabbit serum (Oncogene Science) in a dilution of $1: 1000$

\section{Quantitation of transgene expression as determined by $X$-gal histochemistry}

Quantitation of transgene expression. We have previously described a manual counting method for quantitation of transgene expression (Borsook, 1994a). Here we describe a computer-assisted method for quantitation that correlates very closely with the results obtained by the manual method. For both manual and computerized quantitation, standardized sections were defined by the following criteria (see also Borsook, 1994a): (1) the shape of the PVN was similar in each case under bright field; (2) at this level, the suprachiasmatic nucleus is clearly defined by its typical nuclear density at the base of the third ventricle; and (3) the distance of the SON from the midline on each side is about the same in each case, just lateral to the plane joining the fornix. Basal expression of the transgene appears as small blue puncta, whereas induccd cxpression appears as progressive cellular filling (Borsook et al., $1994 \mathrm{a}, \mathrm{b})$. Because there is no endogenous background X-gal staining, a standard limit level could be set based on control (uninduced) sections previously manually quantitated, approximately 300 blue puncta per PVN section (see Borsook et al., 1994a). Briefly, sections were placed on a Leitz Microscope and an image was transferred via an MT1 CCD 

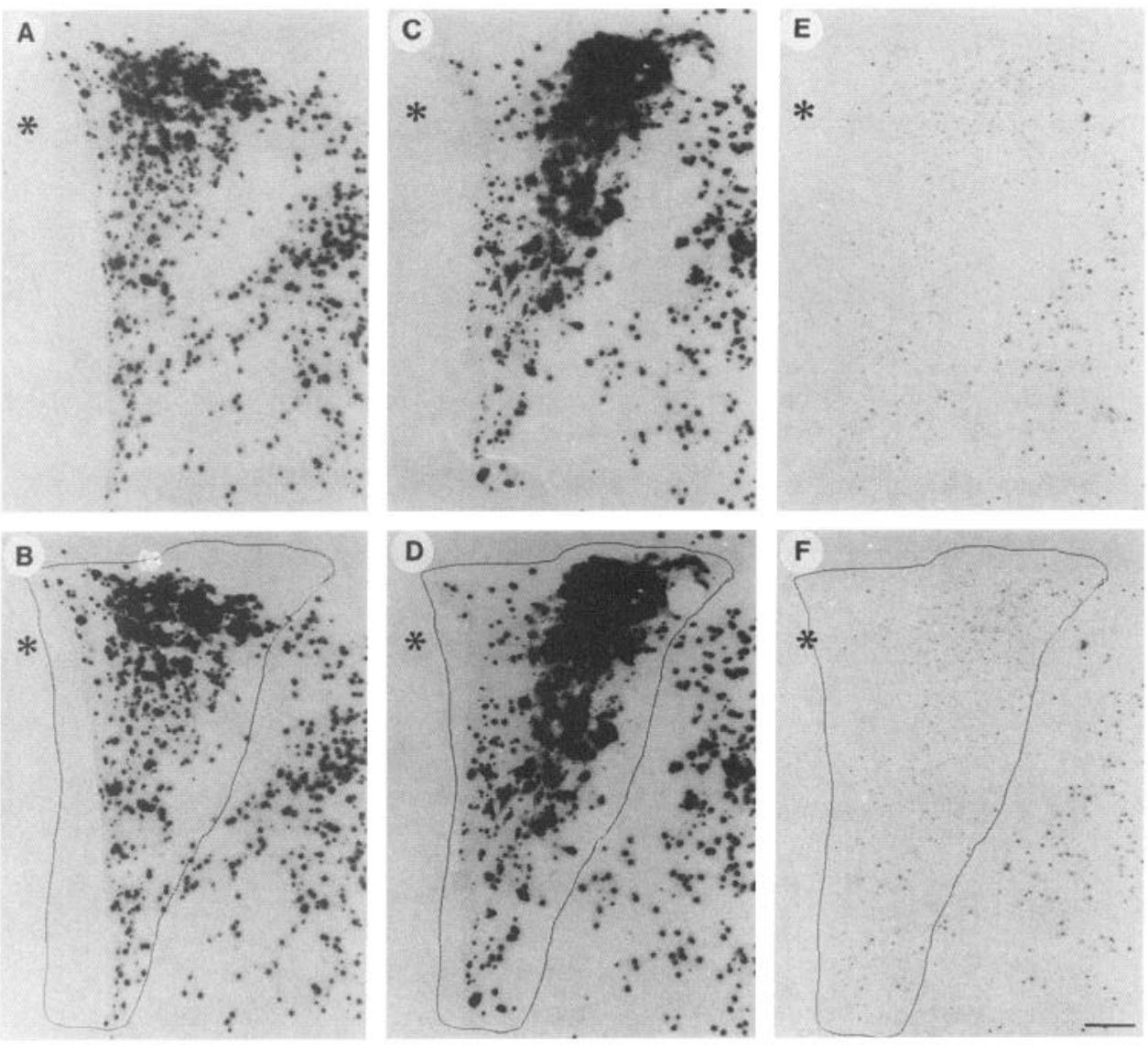

Figure 1. Examples of computer-assisted quantitation: coronal images of the right PVN stained for $\beta$-galactosidase activity, as seen though the $\mathrm{mi}$ croscope $(A, C, E)$, and the same images digitized for quantitation $(B, D, F)$. Transgene expression is shown after 1.5 M saline injected intraperitoneally $(A$, $B) ; 24 \mathrm{hr}$ morphine pretreatment $(8 \mathrm{mg}$ pellet, s.c.) followed by $1.5 \mathrm{M}$ saline injected intraperitoneally $(C, D)$; and chronic morphine $(7 \mathrm{~d}$; s.c. pellets, 8 $\mathrm{mg} \times 3 \mathrm{~d}$ and $25 \mathrm{mg} \times 4 \mathrm{~d})$ treatment only $(E, F)$. There is no background activity and $\beta$-galactosidase staining is clearly observed. In $B, D$, and $F$ the lines surrounding the PVN define the areas used for quantitation of transgene expression. What cannot be seen in the figures is that $\beta$-galactosidase staining is scored with a computer-generated overlay that exactly matches the pattern of transgene expression. Only the total area of $\beta$-galactosidase expression is computed, that is, only positive staining enclosed by the line around the PVN and not the relative area within the line surrounding the nucleus. In these examples the scores are 15,529 pixels for $1.5 \mathrm{M}$ saline, 28,071 pixels for morphine pretreatment followed by $1.5 \mathrm{M}$ saline, and 37 pixels for chronic morphine alone. Animals were killed $6 \mathrm{hr}$ after $1.5 \mathrm{M}$ hypertonic saline $(A-D)$, and after $7 \mathrm{~d}$ in the chronic morphine case $(E, F){ }^{*}$, top of the third ventricle. Scale bar, $50 \mu \mathrm{m}$.
72 Dage Camera onto a computer. Corresponding single sections, as defined above, were analyzed using MCID $\mathrm{M} 4$ version 1.2 software. The region of interest was defined by drawing a line around the paraventricular nucleus, and $\beta$-galactosidase expression within the target area was quantified as total area $\left(\mu \mathrm{m}^{2}\right)$ within the section that was $\beta$-galactosidase positive. The standard cutoff was set at 0.6258 , which represents the minimal optical density for a $\beta$-galactosidase punctum to be considered a target. Data was then subjected to statistical analysis (Student's $t$ test).

Quantitation of in situ hybridization. After defining the PVN by its anatomy, using the criteria described above, the microscope was configured for dark-field viewing. Only the right PVN was used for counting in each case. Positive cells were defined as those where hybridization of the probe was greater than $10 \times$ background. The fimbria of the hippocampus, a region with few proenkephalin-expressing cells, was used to define the background. Grains were counted in a defined area $(0.1 \times 0.1 \mathrm{~mm})$ for each case using a graticule. The total number of cells for each case ( $n=4$ in each group) was analyzed using the Student's $t$ test; values of $p<0.01$ were considered significant.

Quantitation of c-Fos expression. Counting of cells positive for c-Fos was performed precisely as described previously (Borsook et al., 1994a,b). Briefly, cells were counted using a graticule placed over the PVN at $40 \times$ magnification. At this magnification, cells are easily visualized. All Fospositive cells, whether lightly or darkly stained, were counted.

\section{Results}

\section{Quantitation of $\beta$-galactosidase expression in the PVN}

Typical images used for computer-assisted quantitation of $\beta$-galactosidase expression in the PVN are shown in Figure 1 under basal conditions (Fig. $1 A, B$ ), with morphine pretreatment prior to a $1.5 \mathrm{~m}$ saline stress (Fig. $1 C, D$ ), and following chronic morphine administration (Fig. $1 E, F$ ). Although these sections are taken from three different cases, the PVN is clearly demarcated from other regions of the hypothalamus in which $\beta$-galactosidase expression is present. There is minimal variation in determination of total area that is $\beta$-galactosidase positive on repeated measurements (i.e., redrawing of the boundary) in each case (see Materials and Methods).

\section{Naloxone-precipitated withdrawal induces transgene expression in the PVN and SON}

An initial experiment was performed to determine whether antagonist-precipitated morphine withdrawal produced induction of the transgene in the same manner as that shown previously for the endogenous gene in the rat (Lightman and Young, 1987). Injection of naloxone $(50 \mathrm{mg} / \mathrm{kg})$ in morphine-dependent mice produced the characteristic behavioral opioid withdrawal syndrome including wet dog shakes, piloerection, and diarrhea (Blasig et al., 1973; Wei et al., 1973). This corresponded with marked induction of transgene expression in the PVN (Figs. 2, 3). Lower doses of naloxone $(10 \mathrm{mg} / \mathrm{kg})$ did not produce a significant withdrawal syndrome in our mouse strain. Most of the cells displaying increased levels of $\beta$-galactosidase activity in response to naloxone-precipitated withdrawal are found in the parvocellular portion of the PVN. Naloxone failed to induce transgene expression in animals that were not morphine dependent (Fig. 2). There was also induction of transgene expression in the SON with naloxone-precipitated morphine withdrawal, but not in other regions of the hypothalamus, such as the ventromedial nucleus, anterior hypothalamus, and lateral hypothalamus. The induction pattern observed in this transgenic model is therefore similar to what has been observed for the endogenous gene in the rat (Lightman and Young, 1987; Harbuz et al., 1991), pro- 

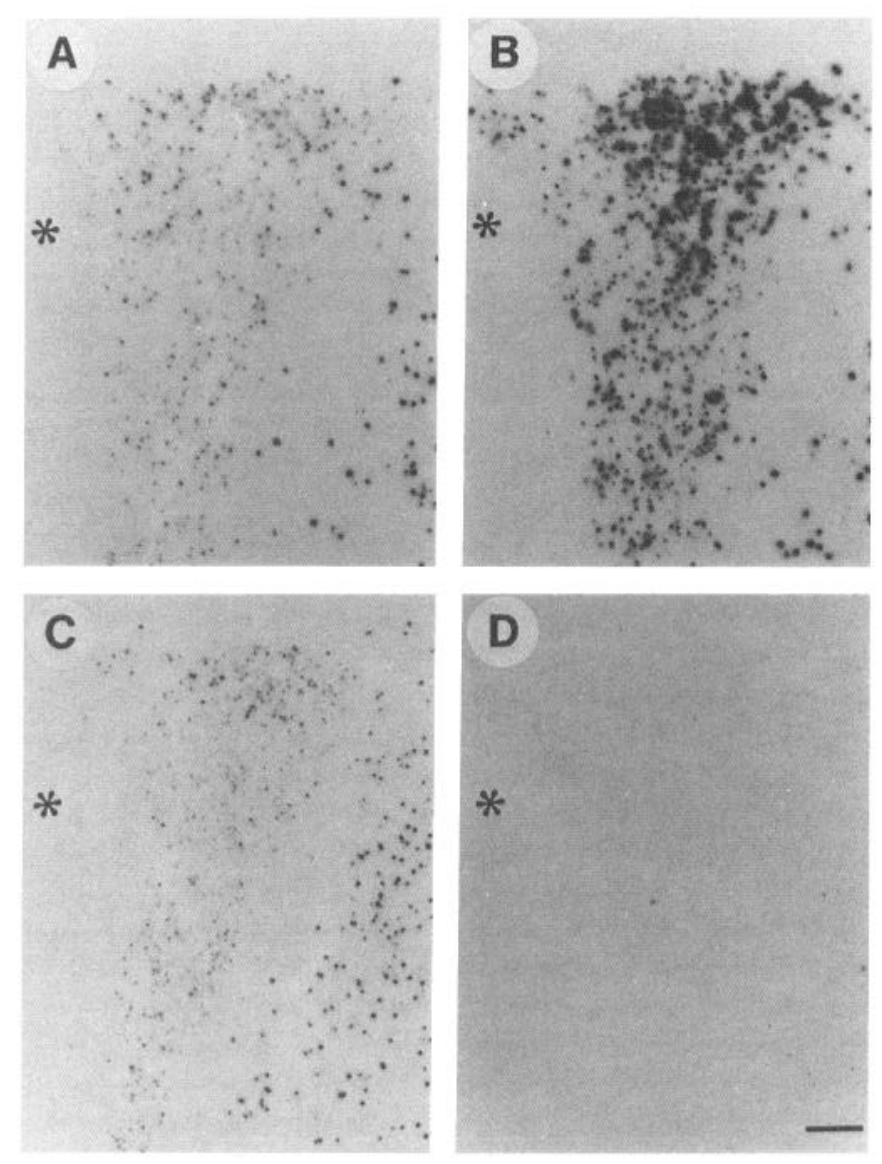

Figure 2. Naloxone-precipitated withdrawal induces and chronic morphine suppresses transgene expression: $40 \mu \mathrm{m}$ coronal sections through the hypothalamus of transgenic mice stained for $\beta$-galactosidase. $A$ and $B$, Naloxone-precipitated withdrawal induces transgene expression in the PVN: control transgenic mouse treated with placebo pellets subcutaneously for $7 \mathrm{~d}$ followed by naloxone $(50 \mathrm{mg} / \mathrm{kg}$, s.c.; $A$ ) compared with mouse treated with morphine pellets subcutaneously $(8 \mathrm{mg} \times 3 \mathrm{~d}$ and then $25 \mathrm{mg} \mathrm{MSO}{ }_{4} \times 4$ d) followed by naloxone $(50 \mathrm{mg} / \mathrm{kg}$, s.c.; $B)$. In both cases, the mice received pellets for $7 \mathrm{~d}$, the pellets were removed under ether anesthesia, mice were injected with naloxone $2 \mathrm{hr}$ later, and the animals were killed $6 \mathrm{hr}$ after the naloxone injection. $C$ and $D$, Chronic morphine inhibits stress-induced transgene expression. $C$, Control transgenic mouse treated with placebo pellet for $7 \mathrm{~d}$. $D$, Mouse treated with chronic $\mathrm{MSO}_{4}$ pellets $(8 \mathrm{mg}$ pellet $\times 3 \mathrm{~d}$ and $25 \mathrm{mg}$ pellet $\times 4 \mathrm{~d}){ }^{*}$, top of third ventricle. Scale bar, $50 \mu \mathrm{m}$.

viding further evidence that transgene expression accurately reflects regulation of the endogenous gene.

\section{Chronic morphine treatment suppresses transgene expression in the hypothalamus}

Chronic morphine has been reported to decrease proenkephalin gene expression in some brain regions (Uhl et al., 1988). We therefore investigated the effects of chronic morphine administration on transgene expression in the PVN. Following chronic morphine administration, expression of the transgene was dramatically suppressed compared with animals that received either placebo pellets or no pellets (Figs. $1 E ; 2 C, D ; 3$ ). This decrease in expression, to almost unobservable levels, was seen throughout the hypothalamus and was not limited to the PVN and SON (see Fig. 6). Animals injected with morphine (10 mg/ $\mathrm{kg}$ ) or normal saline intraperitoneally every $6 \mathrm{hr} \times 5 \mathrm{~d}$ displayed a level of suppression of transgene expression that was similar

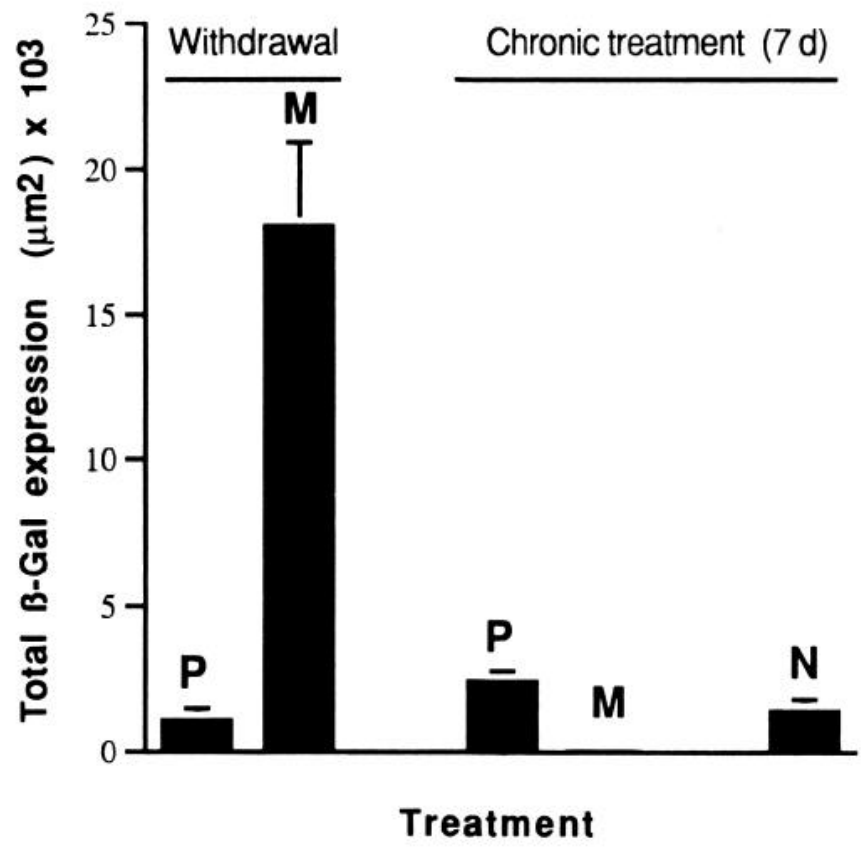

Figure 3. Quantitation of transgene expression in the PVN following naloxone-precipitated withdrawal or chronic morphine treatment. Naloxone-precipitated withdrawal in morphine-tolerant mice (withdrawalM) produces a significant increase $(p<0.001$, Student's $t$ test; $n=4)$ in transgene expression in the PVN compared with control mice (Withdrawal, $P$ ), as shown in the bar graphs on the left (Withdrawal). Chronic morphine (Chronic treatment, $M$ ) administration $(8 \mathrm{mg} \times 3 \mathrm{~d}$ and then $25 \mathrm{mg} \times 4 \mathrm{~d}$ by s.c. pellets) decreases expression to undetectable levels compared with control animals receiving placebo pellets (Chronic treatment, $P$ ) for the same duration. Note that chronic naltrexone (Chronic treatment, $N$ ) has no significant independent effect on transgene expression compared with control mice (Student's $t$ test; $n=4$ ).

to the animals that received morphine pellets (data not shown). There were no differences between the placebo pellet and the no-treatment conditions.

Chronic administration of naltrexone pellets had minimal effects on transgene expression (Fig. 3). While there was some slight increase in the intensity of puncta, there was no filling of cells with the $\beta$-galactosidase reaction product, the indicator of substantial induction of the transgene. Increasing the dose of naltrexone to $25 \mathrm{mg}$ pellets did not produce any more significant induction of the transgene in the PVN compared with $10 \mathrm{mg}$ pellets (data not shown).

\section{Effects of pretreatment with opioid agonists and antagonists on stress-induced transgene expression in the PVN}

Acute or subacute pretreatment with morphine enhances stressinduced expression of the transgene. Acute or subacute morphine administration has not been shown to produce significant effects on proenkephalin gene expression in the CNS. However, opioid modulation of other physiologic or pharmacologic stimuli has not been thoroughly investigated. Using our transgenic model we therefore investigated the ability of morphine to modulate stress regulation of the proenkephalin gene. Administration of morphine $(10 \mathrm{mg} / \mathrm{kg}$, i.p.) $4 \mathrm{hr}$ prior to a hypertonic saline stressor (acute condition) or administration of a morphine pellet $(8 \mathrm{mg})$ for $24 \mathrm{hr}$ prior to a hypertonic saline stressor (subacute condition) produced a marked enhancement of the already substantial stress-induced increase in transgene expression within 
the PVN (Figs. 4, 5). These differences were statistically significant for both the acute $(p<0.001)$ and subacute $(p<0.05)$ pretreatments compared to placebo pretreatment (Fig. 5). Serial sections through representative cases of animals that received placebo, morphine $(8 \mathrm{mg})$, or naltrexone $(10 \mathrm{mg})$ pellets for 24 $\mathrm{hr}$ prior to a hypertonic saline stress demonstrate that the changes in transgene expression seen within the PVN are present throughout the rostral-caudal extent of the nucleus (data not shown). Similar changes are seen in the SON (Fig. 6).

A previous quantitative comparison of transgene expression in the PVN indicates that hypertonic saline stress produces an increase in $\beta$-galactosidase expression (cellular filling) in cells that had previously expressed puncta, but no new cells become $\beta$-galactosidase positive (Borsook et al., 1994a). Following morphine pretreatment, stress induction of transgene expression by hypertonic saline stress within the PVN or SON is more rapid (not shown) and quantitatively greater than any independent stressor heretofore examined (Borsook et al., 1994a,b). Moreover, regions of the hypothalamus, in which transgene expression is not induced by hypertonic saline stress, reveal cellular filling, and therefore, high levels of induction when stress follows morphine pretreatment. These areas include the preoptic region (Fig. 7A,B); the nucleus circularis (NC), a small isolated magnocellular region of the anterior hypothalamus (Fig. $7 C, D$ ); the lateral hypothalamus ( $\mathrm{LH}$; Fig. $7 E, F)$; the ventromedial nucleus (Fig. $7 G, H$ ); and, in the retrochiasmatic supraoptic nucleus (RSON), neurons on the ventral border of the hypothalamus below the arcuate nucleus (Fig. $7 G, H$ ). In some areas (CI, LH, RSON), expression of the transgene colocalizes with vasopressin-immunoreactive cells (Borsook et al., unpublished observations). We conclude that acute or subacute morphine administration markedly sensitizes restricted populations of proenkephalin-expressing hypothalamic neurons to stress. Chronic opioid pretreatment ( $7 \mathrm{~d}$ ) prior to hypertonic saline stress inhibits this response (Fig. $4 F$ ) in addition to suppressing basal expression, consistent with marked desensitization of proenkephalin gene expression.

Subacute pretreatment with naltrexone inhibits stress-induced expression of the transgene. To determine whether pretreatment with the opioid antagonist naltrexone would produce an opposite effect to morphine pretreatment, naltrexone pellets were administered for $24 \mathrm{hr}$ prior to hypertonic saline stress. Pretreatment with naltrexone inhibits stress induction of transgene expression, below the expected level observed in mice receiving only hypertonic saline injections (Figs. 4, 5). Subacute naltrexone treatment alone did not produce an observable effect on transgene expression (data not shown).

The endogenous proenkephalin $M R N A$ in the PVN parallels regulation of the transgene by opioids and stress. We have previously shown that transgene expression within the PVN correlates closely with expression of the endogenous mouse proenkephalin mRNA following stress, and that the transgene colocalizes with met-enkephalin peptides as determined by double-label immunohistochemistry (Borsook et al., 1994a). Here we demonstrate a similarly close correlation between levels of expression of the endogenous proenkephalin mRNA and the transgene after subacute administration of morphine or naltrexone followed by a hypertonic saline stress. The endogenous gene showed significantly higher levels of stress-induced expression following the morphine pretreatment than after placebo $(p<0.005)$. Naltrexone pretreatment inhibited stress-induced proenkephalin mRNA expression (Figs. 8, 9).
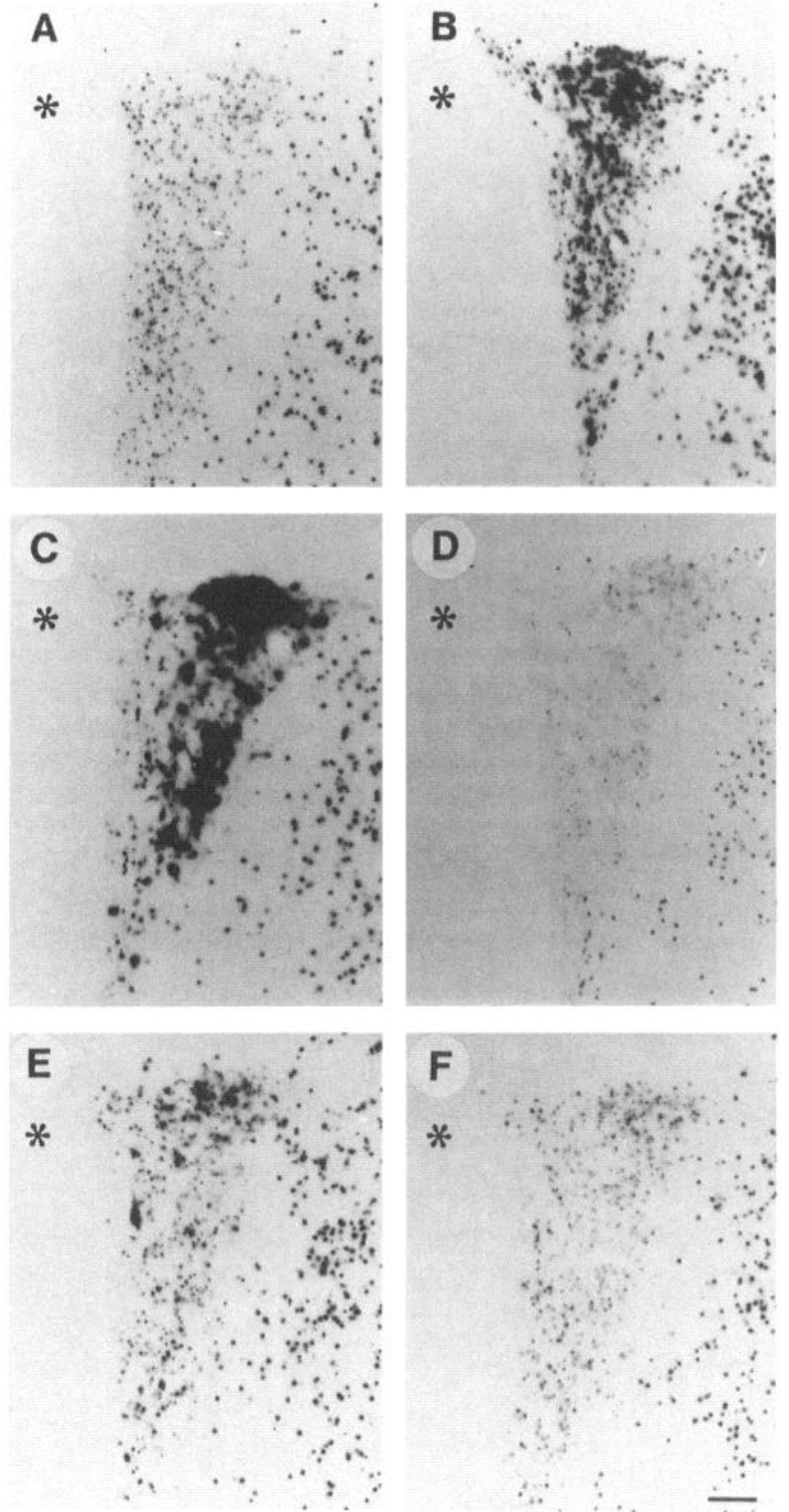

Figure 4. Subacute morphine pretreatment prior to a $1.5 \mathrm{~m}$ saline stress "superinduces" transgene expression in the PVN. $A-F$, Corresponding coronal sections $(40 \mu \mathrm{m})$ taken at the same anatomical level of the right PVN stained for $\beta$-galactosidase. In all cases mice were killed $6 \mathrm{hr}$ after intraperitoneal injections of either $0.15 \mathrm{M}(A)$ or $1.5 \mathrm{M}(B-F)$ saline. $A$ and $B$, Expression of the transgene in PVN in mice treated with placebo pellets for $24 \mathrm{hr}$ followed by $0.15 \mathrm{M}$ saline $(A)$ or $1.5 \mathrm{M}$ saline stress $(B)$. Expression is essentially identical to animals that received corresponding saline treatments only (see text). Subacute morphine pretreatment (8 mg pellet, s.c., for $24 \mathrm{hr}$ ) markedly enhances $\beta$-galactosidase induction in response to an injection of $1.5 \mathrm{M}$ saline $(C)$ compared with control $(B)$. Subacute naltrexone $(10 \mathrm{mg}$ pellet, s.c., for $24 \mathrm{hr}$ ) suppresses induction of the transgene in response to an injection of $1.5 \mathrm{M}$ saline $(D)$ compared with control $(B)$. Note that the level of expression in this case $(D)$ is similar to the unstressed $(0.15 \mathrm{M}$ saline-treated) animal $(A)$. Chronic morphine pretreatment $(8 \mathrm{mg} \times 3 \mathrm{~d}$ and then $25 \mathrm{mg} \times 4 \mathrm{~d})$ inhibits stress (1.5 M saline)-induced transgene expression in the PVN $(F)$ compared with a control receiving a placebo pellet for $7 \mathrm{~d}$ followed by a 1.5 M saline stress $(E) .^{*}$, top of the third ventricle. Scale bar, $50 \mu \mathrm{m}$. 


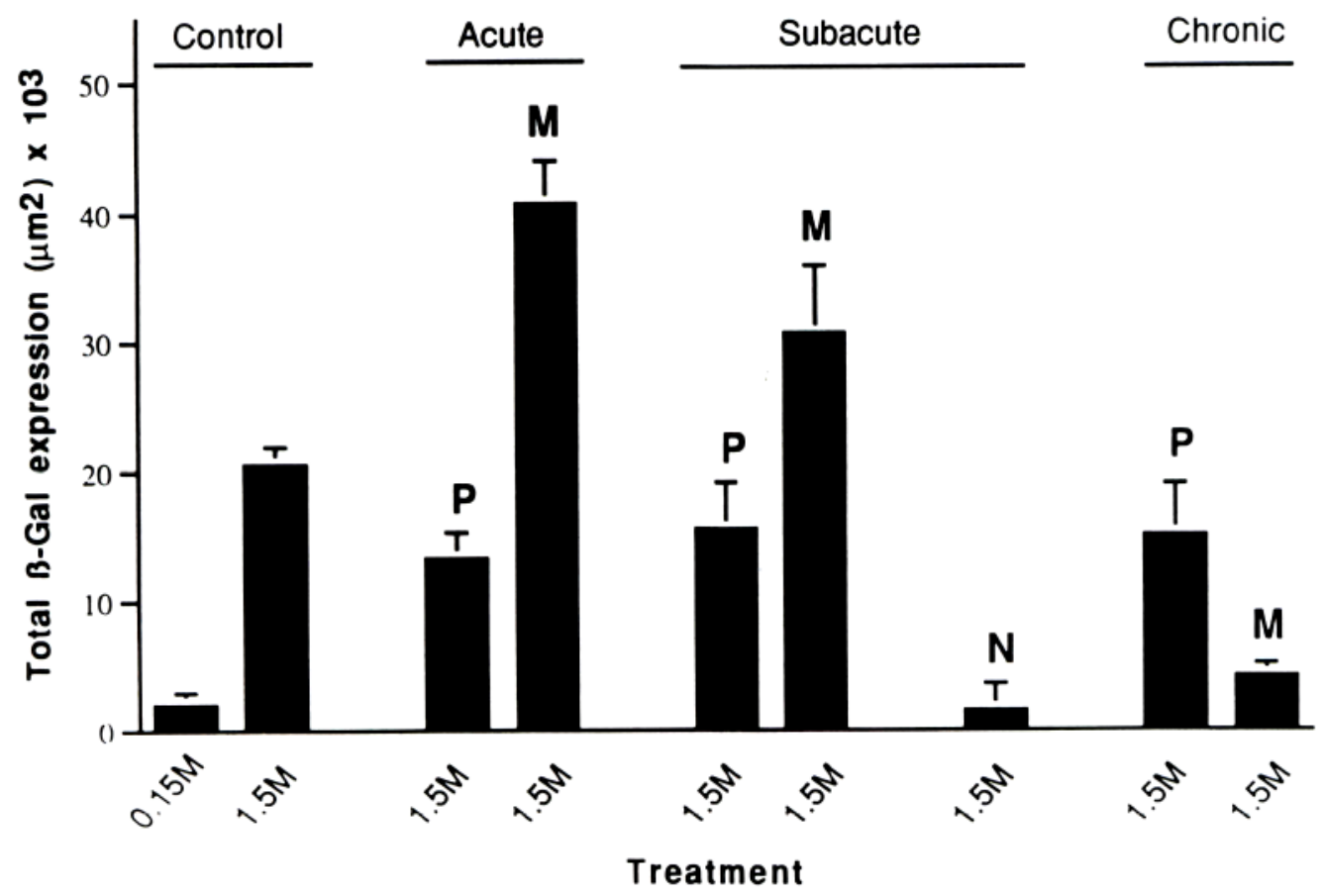

Figure 5. Quantitation of effects of opioid agonist and antagonist pretreatment on saline stress regulation of transgene expression in the PVN. The graph shows quantification of the effects of various treatments (shown at the top) on the induction of the transgene in corresponding sections from the right PVN. The increase in transgene expression produced by $1.5 \mathrm{M}$ saline versus $0.15 \mathrm{M}$ saline was significant $(p<0.01$, Student's $t$ test; $n=4)$. Acute administration of morphine (Acute, $M)(10 \mathrm{mg} / \mathrm{kg}$, i.p., $4 \mathrm{hr}$ prior to the saline stressor) produced a significant increase in expression compared with the acute control animals (Acute, $P)(p<0.001$, Student's $t$ test; $n=4)$. Subacute administration of morphine $($ Subacute, $M)$ also produced a significant increase in transgene expression over the control $(p<0.05$, Student's $t$ test; $n=4)$, while subacute administration of naltrexone (Subacute, $N$ ) prior to the $1.5 \mathrm{M}$ saline produced a significant inhibition of transgene expression compared with placebo-treated animals $(p<0.001$, Student's $t$ test; $n=4)$. The level of expression in the subacute naltrexone case was similar to levels of transgene expression in mice that received only normal saline (Control, $0.15 \mathrm{M}$ ). Chronic morphine administration (Chronic, $M$ ) prior to the saline stressor inhibits stress-induced expression of the transgene $(p<0.05$, Student's $t$ test; $n=4)$ compared with chronic placebo (Chronic, $P)$ treatment or with the acute $(p<0.001$, Student's $t$ test; $n=4)$ or subacute $(p<0.001$, Student's $t$ test; $n=4)$ morphine administration.

Figure 6. Sections through the right hypothalamus showing effects of opioid agonist or antagonist treatments on the supraoptic nucleus $(\mathrm{SON})$ : sections through the right hypothalamus stained for $\beta$-galactosidase activity from mice that received subacute $(A-C)$ or chronic $(D-F)$ treatments. $A$, Placebo pellet followed by $1.5 \mathrm{~m}$ saline $(B)$ morphine pellet $(8 \mathrm{mg})$ followed by $1.5 \mathrm{M}$ saline $(C)$ naltrexone pellet $(10 \mathrm{mg})$ followed by $1.5 \mathrm{~m}$ saline. Note that the level of induction of the transgene in the SON parallels induction in the PVN. $D$, Chronic placebo pellet control. $E$, Chronic morphine pellet $(8 \mathrm{mg} \times 3 \mathrm{~d}$; $25 \mathrm{mg} \times 4 \mathrm{~d}) . F$, Chronic naltrexone pellet $(10 \mathrm{mg} \times 7 \mathrm{~d})$. Note that morphine produces downregulation of transgene expression. In the subacute group, mice were killed $6 \mathrm{hr}$ after saline; the chronic group mice were killed after $7 \mathrm{~d}$ treatment. *, third ventricle; $f$, fornix; $A H$, anterior hypothalamus; $o t$, optic tract; horizontal arrow, PVN; vertical arrow, SON. Scale bar, $100 \mu \mathrm{m}$.
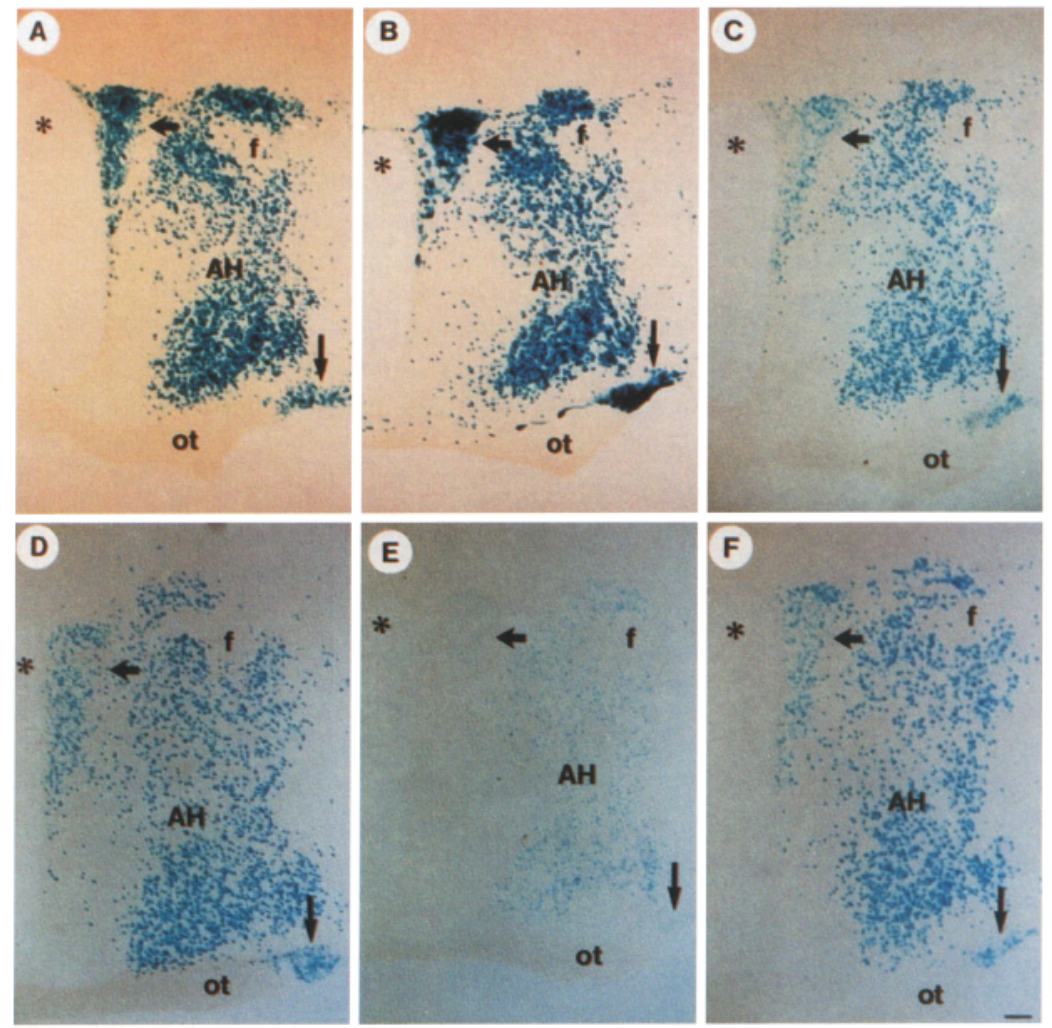

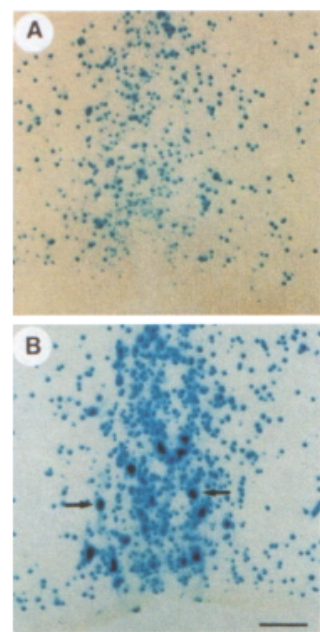
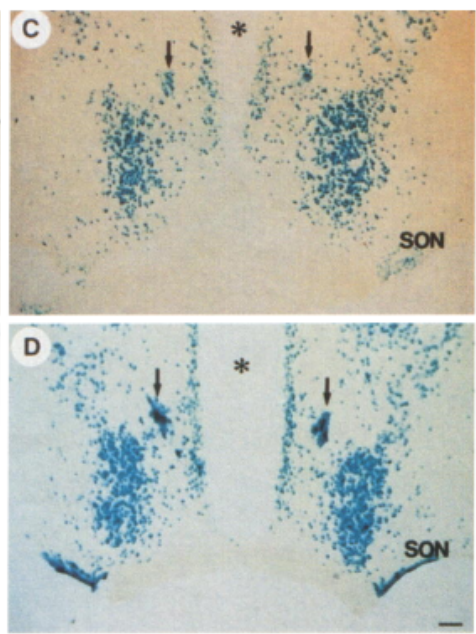
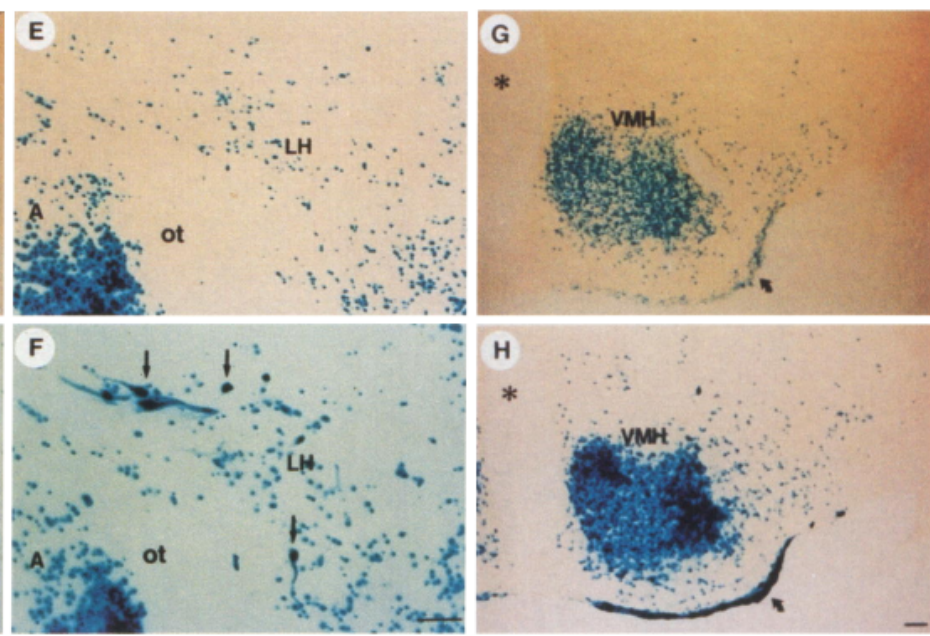

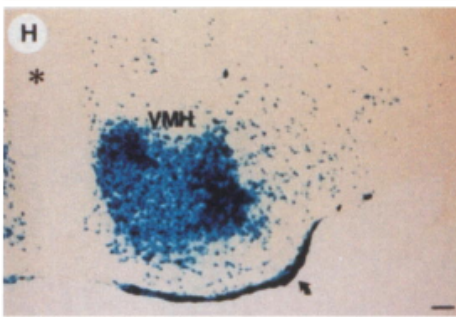

Figure 7. Induction of the transgene in various regions of the hypothalamus in control animals receiving placebo pellets $+1.5 \mathrm{~m}$ saline $(A, C, E$, $G)$ compared with morphine-treated animals $+1.5 \mathrm{~m}$ saline $(B, D, F, H)$. The photomicrographs show induction (arrows; compare control vs treated) of the transgene in neurons by morphine prior to the stressor in the medial preoptic region $(B)$, the nucleus circularis $(E)$, the lateral hypothalamus $(F)$, and the retrochiasmatic supraoptic nucleus along the ventral border of the hypothalamus at the level of the arcuate nucleus $(G)$. *, third ventricle; $M P O$, medial preoptic region; $L H$, lateral hypothalamus; $o t$, optic chiasm; $A$, central amygdaloid nucleus; $V M H$, ventromedial hypothalamic nucleus.

\section{C-Fos expression correlates with transgene expression in the $P V N$ : acute morphine increases Fos in the PVN}

We have previously demonstrated that c-Fos is induced in cells that also show stress induction of the proenkephalin transgene (Borsook et al., 1994b). As an independent marker of the cellular actions of opioids, we therefore examined the effects of opioids on c-Fos expression in the PVN. Figures 10 and 11 show the effects of acute, subacute, and chronic morphine administration prior to a saline stress on c-Fos expression in the PVN. Acute administration (acute-M) of morphine alone $(10 \mathrm{mg} / \mathrm{kg}$, i.p.) produces a significant increase in c-Fos staining in the PVN 1 $\mathrm{hr}$ after the injection compared with vehicle control animals ( $p$ $<0.001$, Student's $t$ test $n=4)$, consistent with previous reports (Chang et al., 1993). Following subacute pretreatment (subacuteM) with a morphine pellet ( $8 \mathrm{mg}$ for $24 \mathrm{hr}$ ), $1.5 \mathrm{M}$ saline produced a larger increase in c-Fos expression in the PVN compared with the placebo-pretreated controls ( $p<0.05$, Student's $t$ test; $n=$ 4). Subacute pretreatment with naltrexone pellets for $24 \mathrm{hr}$ significantly inhibited the stress-induced expression of c-Fos in the PVN compared with controls ( $p<0.02$, Student's $t$ test; $n=$ 4). Expression of c-Fos was significantly inhibited in mice that received chronic morphine pellets (chronic-M) for $7 \mathrm{~d}(8 \mathrm{mg} \times$ $3 \mathrm{~d}$ and $25 \mathrm{mg} \times 4 \mathrm{~d}$ ) followed by a $1.5 \mathrm{~m}$ saline stress compared with mice receiving placebo pellets for the same time $(p<0.001$, Student's $t$ test; $n=4)$. These results demonstrate that subacute morphine administration does not inhibit hypertonic salineinduced c-Fos expression, but chronic morphine expression does.

\section{Discussion}

Here we use our transgenic model to examine the effects of acute, subacute, and chronic opioid administration on stress regulation
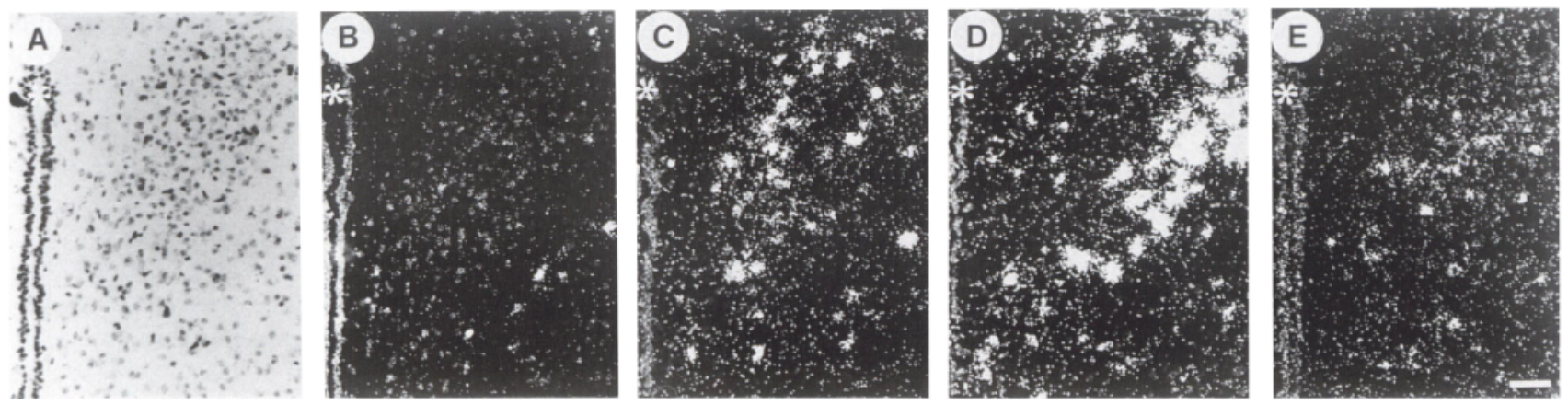

Figure 8. Morphine pretreatment enhances and naltrexone treatment suppresses expression of endogenous proenkephalin mRNA expression in the PVN in response to a $1.5 \mathrm{M}$ saline stress: corresponding bright-field $(A)$ and dark-field $(B-E)$ photomicrographs of $14 \mu \mathrm{m}$ coronal sections through the PVN processed for in situ hybridization of endogenous proenkephalin mRNA. In all cases mice were killed $4 \mathrm{hr}$ after intraperitoneal injections of either $0.15 \mathrm{M}(B)$ or $1.5 \mathrm{M}(C-E)$ saline. Expression of proenkephalin mRNA is shown in the PVN of mice treated with placebo pellets for $24 \mathrm{hr}$ followed by $0.15 \mathrm{M}$ saline $(B)$ or $1.5 \mathrm{M}$ saline stress $(C)$. Subacute morphine pretreatment $(8 \mathrm{mg}$ pellet, s.c., for $24 \mathrm{hr}) \mathrm{markedly}$ enhances induction of the mRNA in response to an injection of $1.5 \mathrm{~m}$ saline $(D)$ compared with the placebo pellet plus $1.5 \mathrm{~m}$ saline $(C)$. Subacute naltrexone $(10 \mathrm{mg}$ pellet, s.c., for $24 \mathrm{hr}$ ) suppresses mRNA induction in response to an injection of $1.5 \mathrm{M}$ saline $(E)$ compared with placebo pellet plus $1.5 \mathrm{M}$ saline control $(C)$. These results match the findings for the transgene induction using the same paradigm (see Fig 4). ${ }^{*}$, top of third ventricle. Scale bar, $50 \mu \mathrm{m}$. 


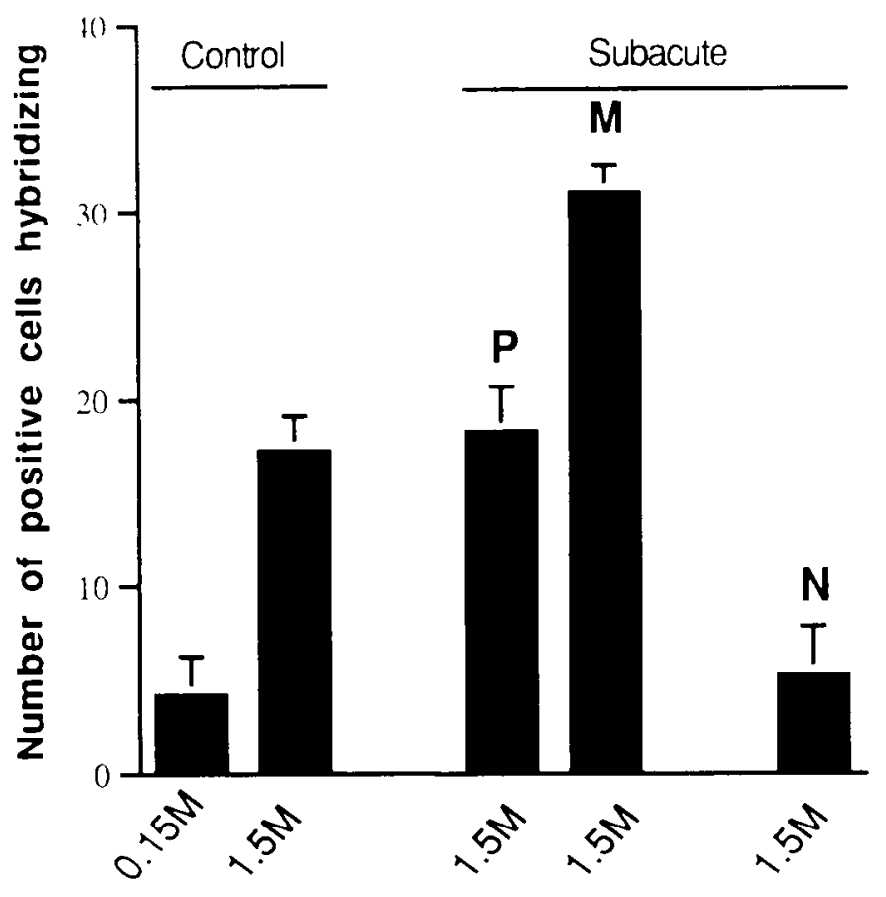

Treatment

Figure 9. Quantitation of endogenous proenkephalin mRNA induction in the PVN. The graph shows the number of positively hybridizing cells within equivalent sections containing the PVN. Only the right PVN was quantitated in each case. In all cases mice were killed $6 \mathrm{hr}$ after receiving intraperitoneal injections of $1.5 \mathrm{M}$ or $0.15 \mathrm{M}$ saline. In placebotreated (Control) animals, $1.5 \mathrm{~m}$ saline produced a significant increase in endogenous proenkephalin compared with animals receiving $0.15 \mathrm{M}$ saline $(p<0.002$, Student's $t$ test; $n=4)$. Morphine pellet-pretreated animals (Subacute, $M$ ) had significantly greater induction in response to a saline stress than animals receiving a placebo (Subacute, $P$ ) pellet $(p<0.005$, Student's $t$ test; $n=4)$. There was no significant difference between naive mice that received a $1.5 \mathrm{M}$ saline stress and mice that received placebo pellets $24 \mathrm{hr}$ prior to the $1.5 \mathrm{~m}$ saline injection (Student's $t$ test); naltrexone (Subacute, $N$ ) administration (10 mg pellets) $24 \mathrm{hr}$ prior to the saline stress inhibited endogenous proenkephalin mRNA compared with placebo controls ( $p<0.05$, Student's $t$ test; $n$ $=4)$.

of proenkephalin gene expression within the hypothalamus. The advantages of the transgenic model are that it is more sensitive and more readily quantified than in situ hybridization and that genomic sequences responsible for the observed regulation are known to be contained within the transgene, making subsequent analysis of transcriptional mechanisms possible. We have previously shown that this transgene is appropriately regulated by stress in the hypothalamus (Borsook, 1994a,b). Taken together with our previous results, the present data help confirm that the information necessary for correct regulation of the proenkephalin gene within the hypothalamus is contained within the transgene.

The effects of opioids on proenkephalin gene expression appear to be complex, with differing effects reported in different cell types (Simantov et al., 1976; Childers et al., 1977; Fratta et al., 1977; Przewlocki et al., 1979; Bianchi et al., 1988). Thus, for example, chronic morphine treatment has been reported to decrease levels of proenkephalin mRNA in the striatum (Uhl et al., 1988) but to increase proenkephalin mRNA in brain or in cell lines (Simantov et al., 1976; Przewlocki et al., 1979; Schwartz, 1988). Chronic administration of morphine has been reported to decrease hypothalamic expression of proopiome- lanocortin, a member of the opioid gene family (Mocchetti et al., 1989). In our model, the effects of morphine depended on the time course of administration and on the presence of other stimuli, such as stress. Chronic morphine administration independently produced a significant decrease in transgene expression in the PVN (Figs. 2, 3) and also produced decreases in other brain regions in which the transgene is expressed, including the amygdala (data not shown) and other hypothalamic areas (Fig. 6).

Naltrexone has been reported to induce expression of proenkephalin mRNA or met-enkephalin peptides (Morris et al., 1988; Tempel et al., 1992). Chronic naltrexone has been reported by one group to produce a small increase in proenkephalin mRNA levels in the hypothalamus (Tempel et al., 1992), but another group did not ubserve the same effect (Sivam et al., 1986). We did not observe any significant changes in transgene expression produced by naltrexone alone as measured by $\beta$-galactosidase histochemistry after $24 \mathrm{hr}$ or $7 \mathrm{~d}$ treatment with either $10 \mathrm{mg}$ or $30 \mathrm{mg}$ naltrexone pellets.

Acute or subacute administration of morphine prior to a hypertonic saline stress produces superinduction of both the transgene (Figs. 4, 5) and endogenous proenkephalin mRNA (Figs. $8,9)$ in the PVN, while naltrexone inhibits this induction of both the transgene and the endogenous gene. Indeed, morphine pretreatment causes stress-induced activation of proenkephalin gene expression in subsets of hypothalamic neurons that have no apparent response to hypertonic saline stress as an independent stimulus (Fig. 7).

Our results are consistent with the hypothesis that acute or subacute administration of morphine sensitizes enkephalinergic hypothalamic neurons to stress. The use of a morphine pellet in the subacute paradigm makes it unlikely that the superinduction is due to mild, behaviorally unobservable withdrawal acting additively with the saline stress. Moreover, administration of opioids chronically, using a paradigm that produces dependence (as demonstrated by the possibility of producing naloxone-precipitated behavioral withdrawal), not only suppresses basal expression, but also inhibits stress-induced expression of the transgene (Figs. 4, 5). The observed induction of c-Fos in these experiments supports the hypothesis that morphine sensitizes enkephalinergic neurons to stress. We have previously shown that c-Fos appears to be coregulated with the proenkephalin gene in the PVN and that it is a useful independent marker of hypothalamic cell activation with more rapid kinetics than those of the transgene (Borsook et al., 1994b). The induction of c-Fos expression by morphine alone, similar to results recently reported for the rat (Chang et al., 1993), suggests that morphine pretreatment activates these hypothalamic neurons prior to and independently of the saline stressor. Chronic morphine administration inhibits stress-induced c-Fos expression, again paralleling the regulation of the transgene (Figs. 10, 11).

It is initially surprising that acute or subacute morphine pretreatment prior to a hypertonic saline stressor causes superinduction of transgene expression. Morphine has principally inhibitory effects on target neurons mediated by $G_{i}$-linked opiate receptors, especially $\mu$ receptors (Casada et al., 1993). Morphine has previously been shown to produce inhibitory effects on proopiomelanocortin-expressing neurons in the hypothalamus, inhibiting $\beta$-endorphin release and synthesis (Bronstein et al., 1990) and inhibiting stimulated corticotrophin-releasing factor release (Tsagarakis et al., 1990). Moreover, there are relatively few $\mu$ receptors expressed on neurons in the PVN (Thompson et al., 

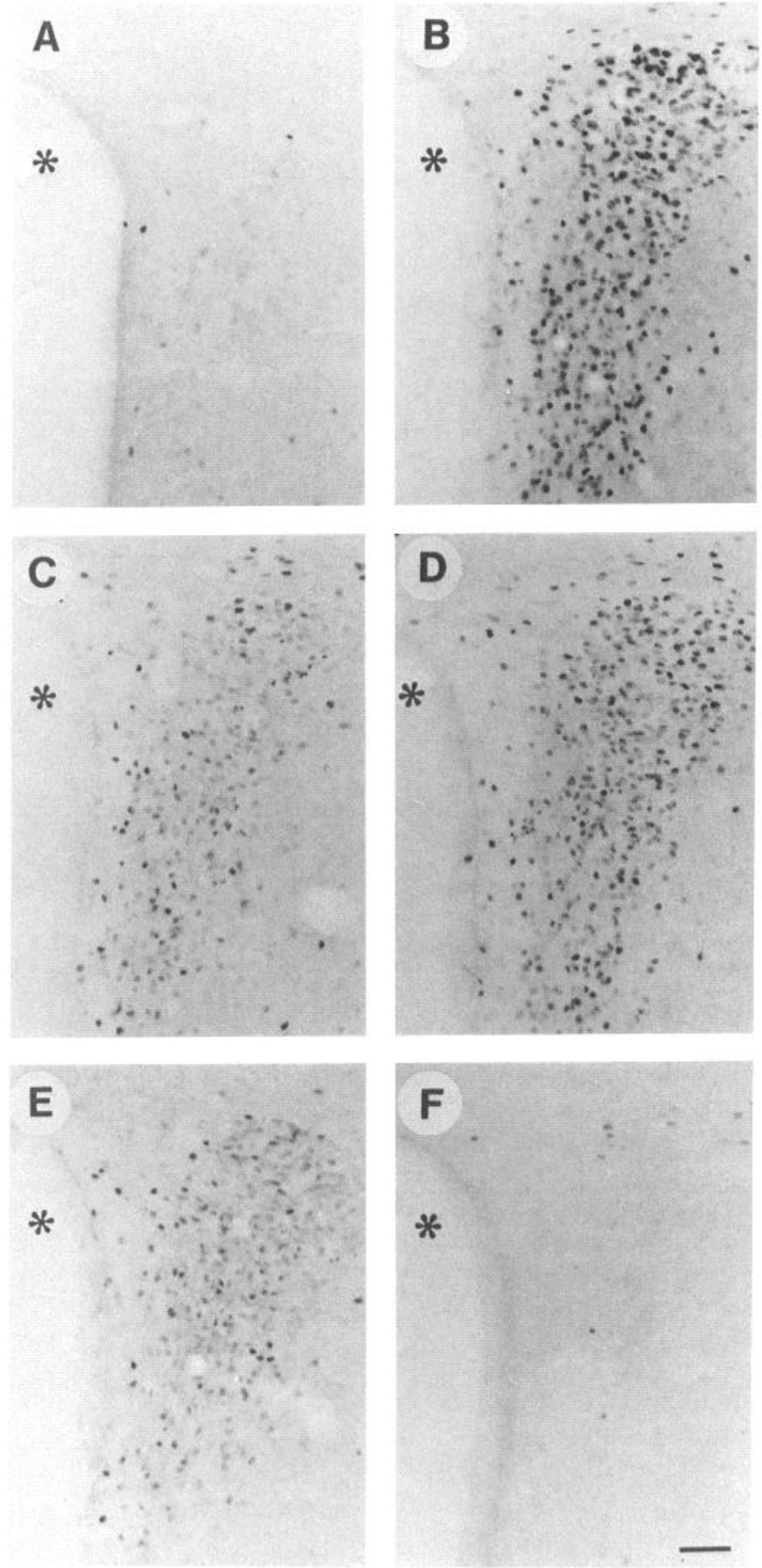

Figure 10. Acute and chronic effects of morphine on the induction of c-Fos in the PVN. $A-F$, Forty-micrometer coronal sections through the $\mathrm{PVN}$ of the hypothalamus processed for Fos immunostaining. Mice received $0.15 \mathrm{M}$ saline (control) $(A)$ or an acute subcutaneous injection of morphine $(10 \mathrm{mg} / \mathrm{kg})$ and were killed $1 \mathrm{hr}$ later, demonstrating that acute morphine induces Fos expression in the PVN. Other mice received a placebo $(C)$ or morphine pellet $(8 \mathrm{mg})$ for $24 \mathrm{hr}$ prior to a $1.5 \mathrm{M}$ saline stress, and were killed $6 \mathrm{hr}$ later. An additional group of mice received chronic placebo pellet for $7 \mathrm{~d}(E)$ or chronic morphine pretreatment ( 8 $\mathrm{mg} \times 3 \mathrm{~d}$ and then $25 \mathrm{mg} \times 4 \mathrm{~d}$ ) followed by a $1.5 \mathrm{M}$ saline stress, and were killed $6 \mathrm{hr}$ later. Note that chronic morphine inhibits the stressinduced expression of Fos $(F)$ compared with placebo-treated animals $(E){ }^{*}$, third ventricle. Scale bar, $50 \mu \mathrm{m}$.

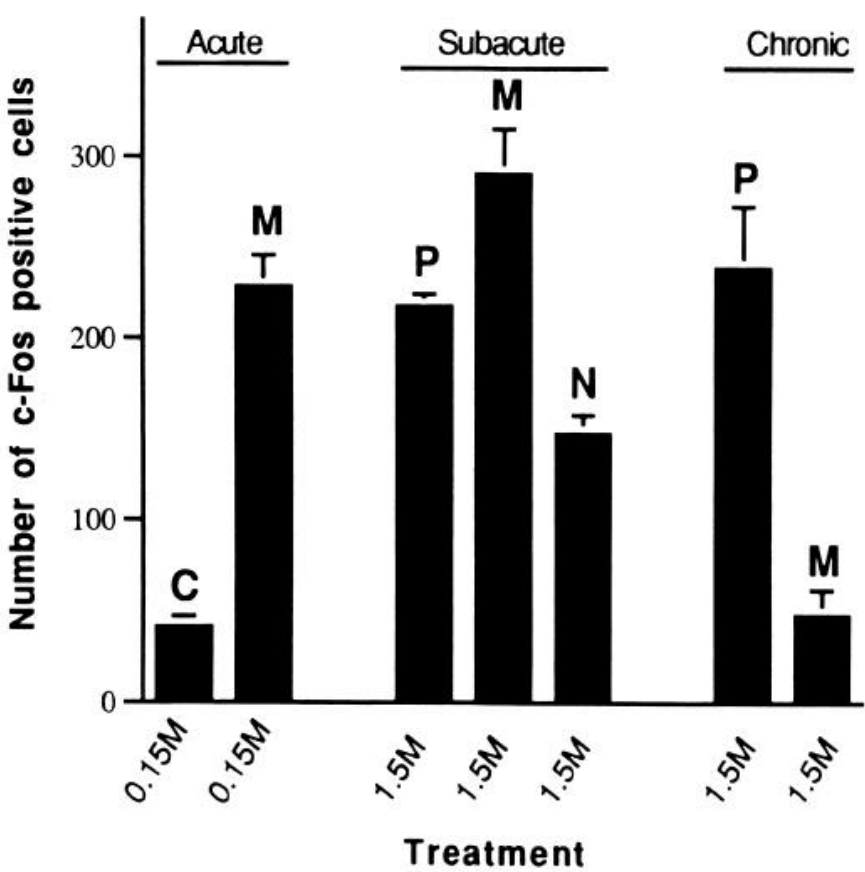

Figure 11. Quantitation of induction of Fos in the PVN following acute morphine and following chronic morphine prior to a hypertonic stress. The graph shows the effects of acute morphine and chronic morphine on the induction of c-Fos immunostaining in the PVN after 0.15 м or 1.5 м saline stress (see Materials and Methods). Note that c-Fos is rapidly induced at $1 \mathrm{hr}$ after acute morphine (Acute, $M$ ) administration compared with controls (Acute, C). Subacute administration of morphine (Subacute, $M$ ) enhances and naltrexone (Subacute, $N$ ) inhibits c-Fos expression when given prior to the saline stress compared with placebo controls (Subacute, P). Chronic morphine, on the other hand, inhibits c-Fos expression (Chronic, $M$ ) compared with placebo controls (Chronic, $P$ ). For details, see Results.

1993) although there are relatively high levels of $\kappa$-opioid receptors (Yasuda et al., 1993). These observations make it unlikely that the effects of morphine on PVN neurons are direct or cell autonomous.

A possible model to account for our findings is one in which the effects of opioids on enkephalinergic neurons in the PVN are mediated via an inhibitory interneuron (e.g., GABAergic) that expresses opiate receptors. There are precedents for apparently excitatory effects of opiates being mediated by opiate inhibition of GABAergic interneurons in the ventral tegmental area (Johnson et al., 1992), hippocampus (Cohen et al., 1992), and periaqueductal gray matter (Pan et al., 1990).

In such a model, independent excitatory and inhibitory inputs onto enkephalinergic neurons in the PVN would be modulated by opioid action. Evidence for excitatory input onto cells in the PVN has been described by a number of investigators (Wuarin et al., 1991; van den Pol et al., 1993). In rats, injection of excitatory amino acids (EAA) into the dentate gyrus produces a significant increase in proenkephalin mRNA that is blocked by a selective NMDA antagonist (Lason et al., 1992). Administration of kainic acid enhances transgene expression in the PVN, and the NMDA receptor antagonist MK-801 inhibits transgene expression throughout the hypothalamus (Borsook et al., unpublished observations). Morphine, D-Ala-2,Me-5-enkephalin, or $\beta$-endorphin have been reported to reduce PVN neuronal activity in isolated slices (Pittman et al., 1980), but connections existing in the intact hypothalamus may have been cut. 
GABA is present in the PVN (Meister et al., 1988; Sakue et al., 1988; Decavel et al., 1989), and GABA-containing boutons that synapse onto PVN neurons have been reported (van den Pol et al., 1993). GABAergic innervation of CRH-containing PVN neurons has been reported to tonically inhibit CRH secretion (see Grossman et al., 1993). Moreover, GABA has been shown to exert an inhibitory influence on proenkephalin gene expression in the striatum (Llorens-Cortes et al., 1990; Reimer et al., 1991), and in the guinea pig hypothalamus GABAergic afferents inhibit proenkephalin mRNA expression (Mitchell et al., 1992).

We hypothesize that the low levels of transgene expression seen under basal conditions reflect predominance of an inhibitory influence on the proenkephalin neuron. In this model, acute or subacute morphine administration inhibits the inhibitory interneuron, thereby disinhibiting the PVN neurons with resultant induction of both c-Fos and transgene expression. Acute stress likely activates the PVN via excitatory amino acid pathways, but may also cause $\beta$-endorphin release, which can, like systemic morphine, inhibit the postulated inhibitory interneuron. The combination of acute or subacute morphine pretreatment with an acute stressor would result in superinduction of the transgene because excitatory amino acids would be acting on a "disinhibited" system. Chronic opioid administration would produce a desensitization of opioid receptors or postreceptor signal transduction systems, in analogy with the locus coeruleus (Nestle, r 1993), permitting the inhibitory interneuron to escape endogenous opioid (e.g., $\beta$-endorphin) control. Enhanced inhibition would lead to even lower than basal levels of transgene expression. The fact that c-Fos is not activated by the stressor after chronic morphine confirms a significant inhibition of the signal transduction apparatus of proenkephalin-containing cells in the PVN. It would be hazardous to interpret the induction of the transgene by naloxone-precipitated withdrawal only in terms of local circuits since naloxone-precipitated withdrawal likely activates excitatory inputs to the PVN, including those from brainstem nuclei (Sawchenko and Swanson, 1982; Ericsson et al., 1994). Extrinsic excitatory input similar to that seen in the locus coeruleus may therefore play a role in the withdrawal paradigm (Aston Jones et al., 1993).

\section{Conclusions}

Opioids may provide a counter-regulatory brake on the stress response at a cellular and organ level by inhibiting the stress response cascade, thus promoting the stability of autonomic functioning (Bicknell, 1985; Lightman, 1988; Przewlocki et al., 1991). Thus, an increase in opioids in the PVN may reflect a mechanism by which the nervous system acts to limit the effects of stress. Our data show that the enkephalinergic neurons within the PVN are responsive to opiates, possibly mediated indirectly via an interneuron. We demonstrate downregulation of gene expression in response to chronic morphine and sensitization to the effects of stress of acute or subacute morphine. In addition to permitting analysis of opioid modulation of the stress response, the transgenic model will provide a useful tool for mechanistic analyses of opioid regulation of endogenous opioid gene expression, including mechanisms of tolerance.

\section{References}

Aston-Jones G, Shiekhattar R, Akaoka H, Rajkowski J, Kubiak P (1993) Opiates influence locus coeruleus neurons by potent indirect and di- rect actions. In: The neurobiology of opiates (Hammer RP, ed), pp 175-202. London: CRC.

Bianchi M, Marini A, Sacerdote P, Cocco E, Brini A, Panerai EA (1988) Effect of chronic morphine on plasma and brain beta-endorphin and methionine enkephalin in pregnant rats and in their fetuses or newborn. Neuroendocrinology 47:89-94.

Bicknell RJ (1985) Endogenous opioid peptides and hypothalamic neuroendocrine neurons. J Endocrinol 107:437-446.

Blasig J, Herz A, Reinhold K, Zieglansberger S (1973) Development of physical dependence on morphine in respect to time and dosage and quantification of the precipitated withdrawal syndrome in rats. Psychopharmacology 33:19-38.

Borsook D, Rosen H, Dressler H, Herrup K, Comb M, Hyman SE (1992) Expression and regulation of a proenkephalin $\beta$-galactosidase fusion gene in the reproductive system of transgenic mice. Mol Endocrinol 6:1502-1512.

Borsook D, Falkowski O, Burstein R, Strassman A, Konradi C, Dauber A, Comb M, Hyman SE (1994a) Stress-induced expression of a human $\beta$-galactosidase fusion gene in the hypothalamus of transgenic mice. Mol Endocrinol 8:116-125.

Borsook D, Konradi C, Falkowski O, Comb M, Hyman SE (1994b) Molecular mechanisms of stress-induced proenkephalin gene regulation: CREB interacts with the proenkephalin gene in the mouse hypothalamus and is phosphorylated in response to hyperosmolar stress. Mol Endocrinol 8:240-248.

Bronstein DM, Przewlocki R, Akil H (1990) Eflects of morphine treatment on pro-opiomelanocortin systems in rat brain. Brain Res 519: 102-111.

Casada JH, Dafny N (1993) Responses of neurons in bed nucleus of the stria terminalis to microiontophoretically applied morphine, norepinephrine and acetylcholine. Neuroendocrinology 32:279-284.

Chang SL, Zadina JE, Niu YF, Thompson J (1993) Chronic morphine treatment attenuates activation of Fos expression in the rat hypothalamus. Soc Neurosci Abstr 19:226.

Childers SR, Simantov R, Snyder SH (1977) Enkephalin: radioimmunoassay and radioreceptor assay in morphine-dependent rats. Eur J Pharmacol 1282:289-293.

Cohen GA, Doze VA, Madison DV (1992) Opioid inhibition of GABA release from presynaptic terminals of rat hippocampal interneurons. Neuron 9:325-335.

Comb M, Birnberg NC, Seasholtz A, Herbert E, Goodman HM (1986) A cyclic AMP- and phorbol ester-inducible DNA element. Nature 323:353-356.

Comb M, Mermod N, Hyman SE, Pearlberg J, Ross ME (1988) Proteins bound at adjacent DNA elements act synergistically to regulate human proenkephalin cAMP inducible transcription. EMBO J 7:37933805.

Decavel C, Dubourg P, Leon-Henri B, Geffard M, Calas A (1989) Simultaneous immunogold labeling of GABA-ergic terminals and vasopressin-containing neurons in the rat paraventricular nucleus. Cell Tissue Res 255:77-80.

Ericsson A, Kovacs KJ, Sawchenko PE (1994) A functional anatomical analysis of central pathways subserving the effects of interleukin-1 on stress-related neuroendocrine neurons. J Neurosci 14:897-913.

Fallon JH, Leslie FM (1986) Distribution of dynorphin and enkephalin peptides in the rat brain. J Comp Neurol 249:293-336.

Fratta W, Yang HYT, Hong J, Costa E (1977) Stability of met-enkephalin content in brain structures of morphine-dependent or footshock-stressed rats. Nature 268:452-453.

Grossman A, Costa A, Navarra P, Tsagarakis S (1993) The regulation of hypothalamic corticotrophin-releasing factor release: in vitro studies. Ciba Found Symp 172:129-143.

Harbuz M, Russell JA, Sumner BE, Kawata M, Lightman SL (1991) Rapid changes in the content of proenkephalin $A$ and corticotropin releasing hormone mRNAs in the paraventricular nucleus during morphine withdrawal in urethane anesthetized rats. Brain Res Mol Brain Res 9:285-291.

Harlan RE, Shivers BD, Romano GJ, Howells RD, Pfaff DW (1987) Localization of preproenkephalin mRNA in the rat brain and spinal cord by in situ hybridization. J Comp Neurol 258:159-184.

Hughes J, Smith TW, Kosterlitz HW, Fothergill LA, Morgan MA, Morris HR (1975) Identification of two related pentapeptides from the brain with potent opiate agonist activity. Nature 258:577-580.

Hyman SE, Comb M, Lin YS, Pearlberg J, Green MR (1988) A common trans-acting factor is involved in transcriptional regulation of neurotransmitter genes by cyclic AMP. Mol Cell Biol 8:4225-4233. 
Hyman SE, Comb M, Pearlberg J, Goodman HM (1989) An AP-2 element acts synergistically with the cyclic AMP- and phorbol esterinducible enhancer of the human proenkephalin gene. Mol Cell Biol 9:321-324.

Iadarola MJ, Douglass J, Civelli O, Naranjo JR (1988) Differential activation of spinal cord dynorphin and enkephalin neurons during hyperalgesia: evidence using cDNA hybridization. Brain Res 455: 205-212.

Johnson SW, North RA (1992) Opioids excite dopamine neurons by hyperpolarization of local interneurons. J Neurosci 12:483-488.

Lason W, Przewocka B, Przewocki R (1992) The effects of excitatory amino acids on proenkephalin and prodynorphin mRNA levels in the hippocampal dentate gyrus of the rat: an in situ hybridization study. Brain Res Mol Brain Res 12:243-247.

Lightman SL (1988) The neuroendocrine paraventricular hypothalamus: receptors, signal transduction $\mathrm{mRNA}$ and neurosecretion. J Exp Biol 139:31-49.

Lightman SL, Young WS (1987) Changes in hypothalamic preproenkephalin A mRNA following stress and opiate withdrawal. Nature 328:643-645.

Llorens-Cortes C, Van-Amsterdam JG, Giros B, Quach TT, Schwartz. JC (1990) Enkephalin biosynthesis and release in mouse striatum are inhibited by GABA receptor stimulation: compared changes in preproenkephalin mRNA and Tyr-Gly-Gly levels. Brain Res Mol Brain Res 8:227-233.

Meister B, Hokfelt T, Geffard M, Oertel W (1988) Glutamic acid decarboxylase- and gamma-aminobutyric acid-like immunoreactivities in corticotropin-releasing factor-containing parvocellular neurons of the hypothalamic paraventricular nucleus. Neuroendocrinology 48:516-526.

Merchenthaler I, Maderdrut JL, Altschuler RA, Petrusz P (1986) Immunocytochemical localization of proenkephalin-derived. Neuroscience 17:325-348.

Mitchell V, Beauvillain IC, Mazzuca M (1992) GABAergic afferents modulate proenkephalin mRNA expression in guinea pig hypothalamic magnocellular dorsal nucleus. Neurosci Lett 144:189-194.

Mocchetti I, Ritter A, Costa E (1989) Down-regulation of proopiomelanocortin synthesis and beta-endorphin utilization in hypothalamus of morphine tolerant rats. J Mol Neurosci 1:33-38.

Morris BJ, Hollt V, Herz A (1988) Opioid gene expression in rat striatum is modulated via opioid receptors: evidence from localized receptor inactivation. Neurosci Lett 89:80-84.

Nestler EJ, Hope BT, Widell KL (1993) Drug addiction: a model for the molecular basis of neural plasticity. Neuron 11:995-1006.

Nguyen TV, Kobierski L, Comb MJ, Hyman SE (1990) The effect of depolarization on expression of the human proenkephalin gene is synergistic with cAMP and dependent upon cAMP-inducible enhancer. J Neurosci 10:2825-2833.

Pan ZZ, Williams JT, Osborne PB (1990) Opioid actions on single nucleus magnus neurons from rat and guinea pig in vitro. J Physiol (Lond) 427:519-532.

Pittman QJ, Hatton JD, Bloom FE (1980) Morphine and opioid peptides reduce paraventricular neuronal activity: studies on rat hypothalamic slice preparation. Proc Natl Acad Sci USA 77:5527-5531.

Polkiewicz RD, Rosen H (1990) Regulated expression of proenkephalin A during ontogenic development of mesenchymal derivative tissues. Mol Cell Biol 10:736-742.

Price J, Turner D, Cepko C (1987) Lineage analysis in the vertebrate nervous system by retrovirus mediated gene transfer. Proc Natl Acad Sci USA 84:156-160.
Przewlocki R, Hollt V, Duka T, Kleber G, Gramsch C, Haarmann I, Herz A (1979) Long-term morphine treatment decreases endorphin levels in rat brain and pituitary. Brain Res 174:357-361.

Przewlocki R, Prewlocka B, Lason W (1991) Adaptation of opioid systems to stress. In: Neurobiology of opioids (Almeida OFX, Shippenberg TS, eds), pp 229-243. Berlin: Springer.

Reimer S, Hollt V (1991) GABAergic regulation of striatal opioid gene expression. Brain Res Mol Brain Res 10:49-54.

Rosen H, Douglass J, Herbert E (1990) Isolation and characterization of the rat proenkephalin gene. J Biol Chem 259:14309-14313.

Sakue M, Saito N, Taniguchi H, Baba S, Tanaka C (1988) Immunohistochemical localization of gamma-aminobutyric acid in the rat pituitary gland and related hypothalamic regions. Brain Res 446:343353.

Sawchenko PE, Swanson LW (1982) the organization of noradrenergic projections from the brain stem to the paraventricular and supraoptic nuclei in the rat. Brain Res Rev 4:275-325.

Schwartz JP (1988) Chronic exposure to opiate agonists increases proenkephalin biosynthesis in NG108 cells. Brain Res 427:141-146.

Simantov R, Snyder SH (1976) Elevated levels of enkephalin in morphine dependent rats. Nature 262:505-507.

Sivam SP, Strunk C, Smith DR, Hong JS (1986) Proenkephalin-A gene regulation in the rat striatum: influence of lithium and haloperidol. Mol Pharmacol 30:186-191.

Sonnenberg JL, Rauscher FJ III, Morgan JI, Curran T (1989) Regulation of proenkephalin by Fos and Jun. Science 246:1622-1625.

Tempel A, Kessler JA, Zukin RS (1990) Chronic naltrexone increases expression of preproenkephalin and preprotachykinin mRNA in discrete brain regions. J Neurosci 10:741-747.

Thompson RC, Mansour A, Akil H, Watson SJ (1993) Cloning and pharmacological characterization of a rat $\mu$ opioid receptor. Neuron 11:903-913.

Tsagarakis S, Rees LH, Besser M, Grossman A (1990) Opiate receptor subtype regulation of CRF-41 release from rat hypothalamus in vitro. Neuroendocrinology 51:599-605.

Uhl GR, Ryan JP, Schwartz JP (1988) Morphine alters preproenkephalin gene expression. Brain Res 459:391-397.

van den Pol AN, Trombley PQ (1993) Glutamate neurons in hypothalamus regulate excitatory transmission. J Neurosci 13:2829-2836.

Waterfield AA, Hughes J, Kosterlitz HW (1976) Cross tolerance between morphine and methionine-enkephalin. Nature 260:624-625.

Watts AG (1992) Disturbance of fluid homeostasis leads to temporally and anatomically distinct responses in neuropeptide and tyrosine hydroxylase mRNA levels in the paraventricular and supraoptic nuclei of the rat. Neuroscience 46:859-879.

Wei E, Loh HH, Way EL (1973) Quantitative aspects of precipitated abstinence in morphine dependent rats. J Pharmacol Exp Ther 184: 398-403.

White JD, Gall CM, McKelvy JF (1986) Proenkephalin is processed in a projection-specific manner in the rat central nervous system. Proc Natl Acad Sci USA 83:7099-7103.

Wuarin JP, Dudek FE (1991) Excitatory amino acid antagonists inhibit synaptic responses in the guinea pig hypothalamic paraventricular nucleus. J Neurophysiol 65:946-951.

Yasuda K, Raynor K, Kong H, Breder CD, Takeda J, Reisine T, Bell GI (1993) Cloning and functional comparison of kappa and delta opioid receptors from mouse brain. Proc Natl Acad Sci USA 90: 6736-6740. 